\title{
Recommendations for travelling with bronchiectasis: a joint ELF/EMBARC/ ERN-Lung collaboration
}

\author{
Michal Shteinberg (1) ${ }^{1}$, Barbara Crossley², Tal Lavie ${ }^{3}$, Sima Nadler², \\ Jeanette Boyd ${ }^{4}$, Felix C. Ringshausen (10 ${ }^{5}$, Tim Aksamit ${ }^{6}$, James D. Chalmers ${ }^{7}$ \\ and Pieter Goeminne ${ }^{8}$
}

Affiliations: ${ }^{1}$ Pulmonology Institute and CF Center - Carmel Medical Center, the Technion - Israel Institute of Technology, Haifa, Israel. ${ }^{2}$ European Lung Foundation Bronchiectasis Patient Advisory Group. ${ }^{3}$ Clinical Pharmacology Unit, Carmel Medical Center, Haifa, Israel. ${ }^{4}$ European Lung Foundation, Sheffield, UK. ${ }^{5}$ Dept of Respiratory Medicine, Hannover Medical School, Member of the German Centre for Lung Research, Hannover, Germany. ${ }^{6}$ Mayo Clinic, Rochester, MN, USA. ${ }^{7}$ Scottish Centre for Respiratory Research, University of Dundee, Ninewells Hospital and Medical School, Dundee, UK. ${ }^{8}$ Dept of Respiratory Medicine, AZ Nikolaas, SintNiklaas, Belgium.

Correspondence: Michal Shteinberg, Pulmonology Institute and CF Center - Carmel Medical Center and the Technion - Israel Institute of Technology, 7 Michal St., Haifa 3436212, Israel. E-mail: michalshatechnion.ac.il

\section{ABSTRACT}

Introduction: People with bronchiectasis frequently request specialist advice to prepare for travelling, but there are few publications providing advice on safe travel with bronchiectasis. There is a need for recommendations on adapting everyday treatment to the requirements during travelling.

Methods: A panel of 13 patient volunteers formulated questions regarding different aspects of travelling, including safety of travel, maintaining regular treatment during travel, and dealing with deterioration while away. Patient input was used to derive a questionnaire and circulated among a panel of bronchiectasis experts. Where $80 \%$ or more experts agreed on a response, a recommendation was made.

Results: A total of 26 bronchiectasis experts answered the questionnaire. Recommendations were made on safety of travel, choice of destinations and activities, choice of travel insurance, carrying medications and devices, maintaining regular treatments in transport, documentation to be provided and oxygen requirements. Some statements did not reach an $80 \%$ agreement; in many cases these statements may be valid for some, but not all bronchiectasis patients.

Conclusions: The general agreement was that it is considered safe for most people with bronchiectasis to travel. Careful planning and preparation with robust communication between patients and their healthcare provider prior to travel for different scenarios is fundamental to a successful journey.

@ERSpublications

It is safe for most people with bronchiectasis to travel. Careful planning and preparation for different scenarios are fundamental to a successful journey. http://bit.ly/2yWEowA

Cite this article as: Shteinberg M, Crossley B, Lavie T, et al. Recommendations for travelling with bronchiectasis: a joint ELF/EMBARC/ERN-Lung collaboration. ERJ Open Res 2019; 5: 00113-2019 [https://doi.org/10.1183/23120541.00113-2019].

This article has supplementary material available from openres.ersjournals.com

Received: 7 May 2019 | Accepted after revision: 3 Aug 2019

Copyright $\odot E R S$ 2019. This article is open access and distributed under the terms of the Creative Commons Attribution Non-Commercial Licence 4.0. 


\section{Introduction}

With increasing availability of transportation, many people of older age and with chronic health conditions are travelling for work or leisure. Bronchiectasis is a chronic condition punctuated by episodes of exacerbations, and treated regularly with oral and inhaled medications and airway clearance $[1,2]$. The requirement for uninterrupted treatment to maintain lung health, the risk of a pulmonary exacerbation, and presence of daily symptoms may all interfere with travel. However, maintaining an active life including travel is important for people with bronchiectasis in order to keep working, maintain family and social relationships, and otherwise enjoy what life has to offer. People with bronchiectasis frequently seek advice from healthcare providers before travel regarding safety of travelling, maintenance of a treatment routine while travelling, providing documentation for airline companies and insurance, security screening, obtaining permission for extra hand luggage when flying, and planning to engage in recreational activities.

EMBARC, the European Multicenter Bronchiectasis Audit and Research Collaboration, is an ERS clinical research collaboration dedicated to advancing research and care of patients with bronchiectasis [3]. One of the aspects of this collaboration involves working with patient volunteers, coordinated by the European Lung Foundation (ELF) to involve people with bronchiectasis in research and promotion of care [4]. Some aspects of this collaboration resulted in patient and caregiver-focused documents [5].

Finding recommendations to prepare people with bronchiectasis for travel was an initiative of individuals who are part of the ELF bronchiectasis patient advisory group (PAG). International guidelines on bronchiectasis care do not refer to care while travelling; recommendations for travelling for people with cystic fibrosis (CF) [6] may not always apply for bronchiectasis, as typically people with bronchiectasis are older and suffer from more prevalent comorbidities than people with $\mathrm{CF}$, and that treatment recommendations in general, including access to drugs and devices, are different between CF and bronchiectasis.

\section{Methods}

Creating a set of recommendations for travel was one of the EMBARC-ELF PAG initiatives. A group of 13 people with bronchiectasis, volunteering as part of the ELF bronchiectasis PAG, together with three bronchiectasis experts (PG, MS and JDC) developed a list of questions that patients may have regarding various aspects of travelling. The questions were circulated among a wider (45 members) PAG and revised according to further recommendations and comments. A questionnaire was then formed incorporating all questions (table 1; similar items were unified into one question) with suggested responses based on the literature and common practice. The questionnaire was then turned into an online survey. An invitation to participate, along with previous similar documents [6-8] were sent to 37 bronchiectasis experts that were globally based and affiliated to EMBARC. The questionnaire contained 10 questions with a total of 41 statements. Experts were asked for an "agree/disagree" response and free-text comments were encouraged for each statement. Responses were recorded and recommendations made where a statement reached $80 \%$ agreement or higher.

In addition, a systematic PubMed search was conducted for the terms: "bronchiectasis"; "non cystic fibrosis bronchiectasis"; "travel"; "high altitude"; supplemental oxygen"; "SCUBA diving"; "cross infection", and also "cystic fibrosis" and "travel" to identify any previous publications on travelling with bronchiectasis.

\section{Results}

No studies were identified that assessed the safety of travel, including air travel, in people with bronchiectasis. Consensus statements regarding travel in people with CF [6] and air travel in chronic obstructive pulmonary disease (COPD) [9] exist but do not make specific recommendations for people with bronchiectasis without CF or COPD, respectively. Documents regarding air travel [10] and SCUBA diving [11] make references to bronchiectasis.

A total of 26 respondents based at institutions in Europe $(n=19)$, United States $(n=3)$, Australia and New Zealand $(n=2)$, India $(n=1)$, and Israel $(n=1)$ completed an online survey. The questions and percentage of responders that agreed are listed in table 1.

\section{Is it safe for all people with bronchiectasis to travel?}

Recommendations:

1) Most people with bronchiectasis can safely travel for vacation or business ( $96 \%$ agreement).

2) It is best to avoid travelling during periods of unstable disease, such as during exacerbations ( $92 \%$ agreement).

3) People with bronchiectasis should consult their healthcare providers and plan for travel $(85 \%$ agreement). 
TABLE 1 Statements included in the questionnaire for experts and percentage agreement

Is it safe for all people with bronchiectasis to travel?

Most people with bronchiectasis can safely travel for vacation or business

It is best to avoid travelling during periods of unstable disease, such as during exacerbations

People with bronchiectasis should consult their healthcare providers and plan for travel

People with very severe bronchiectasis (e.g. candidate for lung transplantation, frequent hospitalisation) should be

Planning travel: are there destinations and conditions that certain people with bronchiectasis should avoid?

People with bronchiectasis should try to avoid travelling to places with high levels of air pollution

People with bronchiectasis should try to avoid travelling to places with a high prevalence of NTM (e.g. Hawaii, USA)

People with bronchiectasis should try to avoid travelling during influenza season

People with bronchiectasis should consult their healthcare professional regarding staying at high altitudes

Travelling to high-altitude destinations labove $3050 \mathrm{~m} / 10000 \mathrm{ft}$ ) should be avoided in people with bronchiectasis ${ }^{\#}$

People with bronchiectasis should preferably travel to destinations with a nearby bronchiectasis centre

What travel insurance should people with bronchiectasis acquire?

Health insurance with coverage of deterioration of a chronic condition

Health insurance with coverage of hospital admission and emergency room visits ${ }^{\#}$

Health insurance with coverage of repatriation ${ }^{\#}$

What medications and devices should people with bronchiectasis carry with them when travelling?

When travelling, it is recommended that people with bronchiectasis should continue taking their regular treatments and make arrangements to take enough medications and equipment for the duration of their travel

When travelling, people with bronchiectasis should consult their healthcare professional or respiratory physiotherapist regarding possible alternatives to heavy or large equipment (e.g. nebulisers)

People with bronchiectasis who suffer frequent pulmonary exacerbations should consult their specialist regarding carrying antibiotics to be used in case of a pulmonary exacerbation when travelling

Medications taken for travel should be properly stored according to manufacturer's recommendations (particularly storage temperature, light exposurel

Electricity requirements (e.g. for a nebuliser) and cleaning instructions should be known prior to travelling and proper adaptations, including checking batteries, should be planned

How can people with bronchiectasis maintain regular treatments when in transport?

It is advised that airway clearance and inhalations are performed while waiting at airports before and after flights. This is best planned ahead and checked with the airport for the best place to do this

While it is not advised to take cough suppressants for bronchiectasis, it may be considered for long flights where a cough may be disturbing to other passengers

Do people with bronchiectasis need to prepare and carry certain documents?

It is advised that patients with bronchiectasis carry documentation from the last clinic/hospitalisation visit, translated into English and preferably also into the language of the country of destination

A document for travel may be prepared and should include: patient's health status, allergies, chronic bacterial infections, regular medications and devices used regularly, recommended medications during exacerbation

It is advised that patients with bronchiectasis carry a translation of a disability card ${ }^{\#}$ (such as a European Union disability parking card) if eligible and where available

When travelling in a guided tour, it is advised that people with bronchiectasis should notify the travel company of their condition

\section{What are oxygen requirements on the flight and at the travel destination?}

Oxygen requirements during commercial flights should be predicted before flight

In people with an $\mathrm{FEV}_{1}<55 \%$ pred or oxygen saturation $<93 \%$ at ambient air, a hypoxia inhalation test should be performed

In people with $\mathrm{FEV}_{1}<1.5 \mathrm{~L}$, a hypoxia inhalation test should be performed ${ }^{\#}$

When planning travel to destinations between 2000 and $3050 \mathrm{~m}$, considerations as for commercial flights should be made

How else can people with bronchiectasis be prepared to travel?

It is recommended that people with bronchiectasis seek advice for travellers and follow recommended immunisations for the destination

Recommended medications while travelling (such as for the prevention of malaria) should be checked for interactions with regular treatments and with treatments during exacerbations

It is recommended that people with bronchiectasis should be stable prior to travelling, if symptoms typical for an exacerbation develop shortly before travelling, treatment should be started and travel postponed if possible

People with severe bronchiectasis and chronic Pseudomonas sp. infection may be advised to receive treatment with an intravenous antibiotic course shortly before travelling to prevent an exacerbation while away

$73 \%$ 
What kind of activities may people with bronchiectasis engage in while on holiday and what precautions are recommended?

It is recommended that people with bronchiectasis should use sun protection while using medications that increase photosensitivity (e.g. ciprofloxacin, doxycycline)

It is recommended that people with bronchiectasis take measures to avoid dehydration while in a hot climate

It is advised that people with bronchiectasis maintain general measures of hygiene to prevent cross-infection: hand hygiene, wearing face masks in crowded places

It is recommended that all people with bronchiectasis refrain from SCUBA diving

It may be safe for people with bronchiectasis to SCUBA dive if they are asymptomatic (no sputum or shortness of breath at the time of diving) and lung function is normal (FEV 1 and peak expiratory flow should both be $>80 \%$ pred, $\mathrm{FEV}_{1}$ /forced vital capacity $>75 \%$ )

It is recommended that people with bronchiectasis should be aware of their own limitations to strenuous activities and limit their participation in such activities accordingly. This refers to sports including hiking, swimming and snorkelling, but also less strenuous activities such as short walks uphill and climbing stairs

Where should people with bronchiectasis get help if they get sick while away?

Prior to travel, people with bronchiectasis should be advised on increasing airway clearance if suffering an exacerbation while away

Prior to travel, people with bronchiectasis should be advised when to take antibiotics, including a recommendation for an oral antibiotic, dose and duration

People with bronchiectasis should be advised when and where to seek medical care at their destination

$100 \%$

$100 \%$

$88 \%$

NTM: nontuberculous mycobacteria; FEV $_{1}$ : forced expiratory volume in $1 \mathrm{~s}$; SCUBA: self-contained underwater breathing apparatus; \% pred: $\%$ predicted. " : 25 out of 26 responded; all other items had 26 responses.

Other statement considered:

- People with very severe bronchiectasis (e.g. candidates for lung transplantation and with frequent hospitalisations) should be advised not to travel abroad (73\% agreement).

There is scarce evidence regarding safety of travel in people with bronchiectasis, and these recommendations are mostly based on a common-sense approach considering the nature of bronchiectasis. Most people with bronchiectasis should have no limitations and often do not seek expert advice before travelling. In other cases, an individual approach should be made, taking into consideration the severity of the condition, oxygen requirements and frequency of exacerbations. Patients and healthcare providers should also consider the length of travel, mode of transportation and the conditions and access to medical care at the destination. Considerations may be different for patients required to travel for business. In such cases, it is the responsibility of the advising physician to support their decision to avoid travelling if such a journey may compromise their health condition. In other cases, the emphasis should be on supporting people, even with life-limiting conditions, to enjoy travel by planning ahead.

\section{Planning travel: are there destinations and conditions that certain people with bronchiectasis should avoid?}

Recommendation:

4) People with bronchiectasis should consult their healthcare professional regarding staying at high altitudes (85\% agreement).

Other statements considered:

- People with bronchiectasis should try to avoid travelling to places with high levels of air pollution (73\% agreement).

- People with bronchiectasis should try to avoid travelling to places with a high prevalence of nontuberculous mycobacteria (NTM) such as Hawaii, USA (38\% agreement).

- People with bronchiectasis should try to avoid travelling during influenza season (35\% agreement).

- Travelling to high-altitude destinations (above $3050 \mathrm{~m} / 10000 \mathrm{ft}$ ) should be avoided in people with bronchiectasis (32\% agreement).

- People with bronchiectasis should preferably travel to destinations with a nearby bronchiectasis centre (31\% agreement).

When staying at high altitudes above $2000 \mathrm{~m}$, several environmental changes may have consequences in people with chronic lung disease and bronchiectasis in particular. Most importantly, as barometric pressure decreases, oxygen concentration decreases. This predisposes all individuals ascending to 
high-altitude destinations to several acute illnesses, including high-altitude pulmonary oedema [12]. In individuals with chronic respiratory conditions causing hypoxaemia at sea level, ascending to high altitudes may worsen hypoxaemia and predispose to respiratory and cardiac failure. While there is no literature on people with bronchiectasis travelling to high-altitude destinations, recommendations regarding individuals with chronic lung diseases such as asthma, COPD and CF exist $[9,12,13]$ and are largely based on exposure to high altitude during air travel. However, although the oxygen concentration during a commercial flight is comparable to that of altitudes of $\sim 2000 \mathrm{~m}$, there are differences in the conditions between air travel and staying at elevated-altitude destinations, mainly the level of physical exertion, and length of exposure to high altitude.

Based on studies in people with COPD during commercial flights and adapting these findings to high-altitude destinations, STREAM et al. [12] recommended that travel to altitudes above $3050 \mathrm{~m}(10000 \mathrm{ft})$ should be avoided in people with COPD. Individuals already on supplemental oxygen should continue to use it during their high-altitude stay, but should increase the flow at rest and during exertion. Patients with an forced expiratory volume in $1 \mathrm{~s}\left(\mathrm{FEV}_{1}\right)<1.5 \mathrm{~L}$ who are not receiving supplemental oxygen should undergo a pre-travel evaluation (using hypoxia simulation or prediction equations; table 2) to determine their need for supplemental oxygen at high altitude, with oxygen prescribed if the $\mathrm{PaO}_{2}$ is predicted to fall below $50 \mathrm{mmHg}$ [10]. While there are many differences between COPD and bronchiectasis, due to scarcity of data on bronchiectasis, and because of similar age and comorbidities as people with COPD, these recommendations can be adopted for people with severe bronchiectasis. However, the recommendation on avoiding altitudes above $3050 \mathrm{~m}$ altogether did not reach agreement for all people with bronchiectasis, and should be individualised on the basis of severity.

Pulmonary exacerbations in people with bronchiectasis are temporally linked to periods of air pollution $[14,15]$. It therefore makes sense to advise people with bronchiectasis against travelling to places with heavy air pollution. This recommendation reached $73 \%$ agreement, with a comment that only those with moderate to severe bronchiectasis and those who are prone to exacerbations [16] should avoid highly polluted places. Information regarding global air quality from multiple monitoring stations is found at: www.aqicn.org/map.

People with bronchiectasis are at risk of acquiring infections with NTM [17-21] with prevalence rates that range from 5\% [17] to 50\% in different series [19]. Series from the United States, especially Hawaii, repeatedly report an elevated prevalence of NTM pulmonary disease. However, little is known about the risk of acquiring infection when travelling to locations with a high risk of NTM for a holiday or even for an extended period of time. It is therefore not recommended for people with bronchiectasis to avoid travelling to places with a high prevalence of NTM. However, this recommendation may be individualised for people with severe bronchiectasis and features of a high risk of NTM infection [17].

When ill during travel, people with bronchiectasis may need to consult local healthcare professionals. For people with very severe bronchiectasis, it may be advised to locate a bronchiectasis centre close to the travel destination and even contact a specialist to inform them about the individual travelling to their area. However, since most people with bronchiectasis may be instructed to self-manage during exacerbations, it is not advised to restrict all individuals to travel exclusively to places with bronchiectasis centres.

Air travel can be associated with an elevated risk of airborne infections, such as viruses. It is reasonable to suspect that travelling during a period of a respiratory disease outbreak (such as influenza) can increase the risk of acquiring influenza and a pulmonary exacerbation. However, while annual influenza immunisation is advised in bronchiectasis guidelines [22], the expert panel does not recommend that people with bronchiectasis avoid travel during influenza season. General precautions for hand hygiene and lung health, including cough etiquette should be followed.

\section{TABLE 2 Examples of equations for predicting hypoxaemia}

$P_{\mathrm{aO}_{2} \mathrm{Alt}}=0.410 \times P_{\mathrm{aO}_{2} \mathrm{Ground}+17.652}$

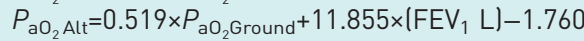

$P_{\mathrm{aO}_{2} \mathrm{Alt}}=0.453 \times \mathrm{P}_{\mathrm{aO}_{2} \mathrm{Ground}+0.386 \times(\mathrm{FEV}} \%$ pred $)+2.44$

$P_{\mathrm{aO}_{2} \mathrm{Alt}}=22.8-(2.74 \times$ altitude in 1000 s of feet $)+0.68 \times P_{\mathrm{aO}_{2} \mathrm{Ground}}$

$P_{\mathrm{aO}_{2} \mathrm{Alt}}$ : predicted arterial oxygen tension at altitude (in millimetres of mercury); $P_{\mathrm{aO}_{2} \mathrm{Ground}}$ : measured arterial oxygen tension at sea level (in millimetres of mercury); $F E V_{1}$ : forced expiratory volume in $1 \mathrm{~s}$; $\%$ pred: \% predicted. Information from [10]. 
What travel insurance should people with bronchiectasis acquire?

Recommendation:

5) People with bronchiectasis should acquire health insurance with a coverage of deterioration of a chronic condition (100\% agreement).

6) People with bronchiectasis should acquire health insurance with a coverage of hospital admission and emergency room visits (100\% agreement).

Other statement considered:

- People with bronchiectasis should acquire health insurance with coverage of repatriation $(68 \%$ agreement).

Bronchiectasis is a chronic illness punctuated by episodes of increasing signs and symptom exacerbations, requiring a change in treatment. While most people with bronchiectasis can self-manage mild exacerbations, the need for specialist care while away may not always be predicted. It is therefore advised to acquire medical insurance that covers a deterioration of a chronic condition, including hospital admission and emergency room visits, especially for those with frequent exacerbations or hospitalisations (100\% agreement). While obtaining travel insurance with a coverage of repatriation was recommended by the majority of experts, it did not reach our consensus definition. Some experts gave the reasoning that repatriation is not a medical need and therefore cannot be recommended. It remains at the decision of the individual travelling to obtain this coverage.

\section{What medications and devices should people with bronchiectasis carry with them when} travelling?

Recommendations:

7) When travelling, it is recommended that people with bronchiectasis should continue taking their regular treatments and make arrangements to take enough medications and equipment for the duration of their travel (100\% agreement).

8) When travelling, people with bronchiectasis should consult their healthcare professional or respiratory physiotherapist regarding possible alternatives to heavy or large equipment such as nebulisers $(100 \%$ agreement).

9) People with bronchiectasis who suffer frequent pulmonary exacerbations should consult their specialist regarding carrying antibiotics to be used in case of a pulmonary exacerbation when travelling (100\% agreement).

10) Medications taken for travel should be properly stored according to manufacturer's recommendations, particularly storage temperature and light exposure (100\% agreement).

11) Electricity requirements (e.g. for a nebuliser) and cleaning instructions should be known prior to travelling and proper adaptations, including checking batteries should be planned (100\% agreement).

It is advisable to provide patients with bronchiectasis with an action plan to be carried when travelling regarding specific medications to be taken when stable and during exacerbations. Antibiotics for an exacerbation should be based on prior sputum cultures and past exacerbation history. Instructions for storage of common medications for bronchiectasis are summarised in table 3 , and it is always advisable for patients to refer to the package insert/summary of product characteristics. In general, it is advisable to take the routine medication for daily care as cabin baggage due to the risk of loss when baggage has been checked in. In addition, medication supply should exceed the planned duration of travel for 1 or 2 weeks in order to be prepared for unexpected delays in return. Nebulisers and chest wall oscillators may be heavy and inconvenient to carry; electricity requirements may vary from place to place and operation by batteries is only possible for some nebulisers. The appropriate means for cleaning and sterilising medical equipment (e.g. nebulisers and mucus-clearance devices) should be available when travelling.

Likewise, carrying parenteral antibiotics may require special storage conditions. It should be discussed with the healthcare provider whether maintaining inhalation therapy is required for the time away, and if possible, switching to a portable nebuliser or metered dose inhaler if appropriate.

Airway clearance during travel needs to be individualised. Some patients can skip a day or two of airway clearance, others can modify to a "simpler" programme for a few days, whereas other patients need to be strictly adherent to their airway clearance program whether at home or travelling. It is possible to switch to an airway clearance regime that requires small, lightweight devices. For example, it may be easy to perform autogenic drainage (which does not require carrying any equipment), or alternatively carrying small and lightweight positive expiratory pressure devices. Some airway clearance techniques can make use of inexpensive everyday objects (tube-in water bottle positive expiratory pressure or drinking straws). Planning ahead is always recommended and should be done with the advice and direction of the healthcare provider. 
Oral antibiotics and antifungals Azithromycin

Erythromycin

Roxithromycin

Clarithromycin
Cap. azithromycin $250 \mathrm{mg}$

Cap. Azenil $250 \mathrm{mg}$

Cap. azithromycin Inovamed $250 \mathrm{mg}$

Cap. Zithromax $250 \mathrm{mg}$

Tab. Zeto $250 \mathrm{mg}$

Tab. azithromycin $250 \mathrm{mg}$

Azenil $200 \mathrm{mg} / 5 \mathrm{~mL}$ powder for oral susp.

Azithromycin $200 \mathrm{mg} / 5 \mathrm{~mL}$ powder for

oral susp.

Azithromycin Teva $200 \mathrm{mg} / 5 \mathrm{~mL}$ powder for oral susp.

Zithromax $200 \mathrm{mg} / 5 \mathrm{~mL}$ powder for oral susp.

Tab. erythromycin $250 \mathrm{mg}$

Tab. Erythro Teva $250 \mathrm{mg} ; 500 \mathrm{mg}$

Tab. Erythrocin $250 \mathrm{mg} ; 500 \mathrm{mg}$

Tab. Erythroped A $500 \mathrm{mg}$

Erythromycin SF granules for oral

susp. $125 \mathrm{mg} / 5 \mathrm{~mL} ; 250 \mathrm{mg} / 5 \mathrm{~mL}$.

$500 \mathrm{mg} / 5 \mathrm{~mL}$

Erythromycin ethyl succinate granules for oral susp. $125 \mathrm{mg} / 5 \mathrm{~mL} ; 250 \mathrm{mg} / 5 \mathrm{~mL}$; $500 \mathrm{mg} / 5 \mathrm{~mL}$

Erythroped SF $250 \mathrm{mg} / 5 \mathrm{~mL} ; 500 \mathrm{mg} / 5 \mathrm{~mL}$

Primacine granules for oral susp. $250 \mathrm{mg} /$

$5 \mathrm{~mL}$

Tab. Rulid 150 mg; 300 mg

Tab. Roxo $150 \mathrm{mg}$

Tab. Karin $250 \mathrm{mg}, 500 \mathrm{mg}$

Tab. Klacid SR $500 \mathrm{mg}$

Tab. clarithromycin $250 \mathrm{mg}, 500 \mathrm{mg}$

Tab. Klaricid XL 500 mg

Prolonged release tab. Mycifor XL $500 \mathrm{mg}$

Caplets Klaridex $250 \mathrm{mg}$

Sachet Klaricid adult $250 \mathrm{mg}$

Klacid paediatric granules for

susp. $125 \mathrm{mg} / 5 \mathrm{~mL}$

Susp. Clarithromycin $125 \mathrm{mg} / 5 \mathrm{~mL} ; 250 \mathrm{mg} /$

$5 \mathrm{~mL}$

Oral susp. clarithromycin $125 \mathrm{mg} / 5 \mathrm{~mL}$;

$250 \mathrm{mg} / 5 \mathrm{~mL}$

Klaricid paediatric susp. $125 \mathrm{mg} / 5 \mathrm{~mL}$

$250 \mathrm{mg} / 5 \mathrm{~mL}$
Cap., tab.: store in the original package in order to protect from light; store below $25^{\circ} \mathrm{C}$

Powder for susp.: store below $25^{\circ} \mathrm{C}$

Reconstituted susp.: store at room

temperature, below $25^{\circ} \mathrm{C}$

After reconstitution of the powder, use the susp. within 5 days; shake immediately

prior to use

Tab.: store in a dry place, below $25^{\circ} \mathrm{C}$

Granules for susp.: store below $25^{\circ} \mathrm{C}$

Reconstituted susp.: store in a refrigerator $\left(2-8^{\circ} \mathrm{C}\right)$; do not freeze

After reconstitution, use the suspension

within 14 days; shake immediately prior to use

Tab.: store below $25^{\circ} \mathrm{C}$

Tab., caplets: store in the original package in order to protect from light and moisture; store below $25^{\circ} \mathrm{C}$ (some manufacturers permit excursions up to $30^{\circ} \mathrm{Cl}$

Sachet: store in a dry place, below $30^{\circ} \mathrm{C}$ Mix the contents of the sachet with a small amount of water before taking to make

the granules easier to swallow

Granules for susp.: store below $30^{\circ} \mathrm{C}$

Reconstituted susp.: store at room

temperature, below $25^{\circ} \mathrm{C}$ lup to $30^{\circ} \mathrm{C}$

according to manufacturer) and use

within 14 days from reconstitution; do not

refrigerate or freeze the reconstituted

suspension; shake immediately prior

to use
Skin photosensitivity: uncommon $\mid \leqslant 1 \%$ ) Alcohol: no special recommendation

Alcohol: may decrease the absorption of erythromycin or enhance effects of alcohol (ethanol); the combination should be avoided

\section{Alcohol: no special recommendation}

Alcohol: no special recommendation 
Amoxicillin

Amoxicillin-clavulanic acid

\section{Doxycycline}

Cap. amoxicillin $250 \mathrm{mg} ; 500 \mathrm{mg}$

Cap. Amoxil 250 mg; $500 \mathrm{mg}$

Cap. Moxyvit $250 \mathrm{mg}$

Cap. Moxyvit forte $500 \mathrm{mg}$

Cap. Moxypen forte $500 \mathrm{mg}$

Amoxicillin powder for oral susp. $125 \mathrm{mg} /$

$5 \mathrm{~mL} ; 250 \mathrm{mg} / 5 \mathrm{~mL}$

Amoxicillin powder for oral susp. SF

$125 \mathrm{mg} / 5 \mathrm{~mL} ; 250 \mathrm{mg} / 5 \mathrm{~mL}$

Moxyvit forte powder for oral susp. $250 \mathrm{mg} /$ $5 \mathrm{~mL}$

Moxypen forte powder for susp. $250 \mathrm{mg} /$

$$
5 \mathrm{~mL}
$$

Tab. Amoxiclav Teva $875 \mathrm{mg}$

Tab. Augmentin $250 \mathrm{mg} ; 500 \mathrm{mg} ; 875 \mathrm{mg}$

Tab. co-amoxiclav $250 \mathrm{mg} ; 500 \mathrm{mg}$

Tab. Maclivan $500 \mathrm{mg}$

Augmentin powder for oral susp. $250 \mathrm{mg} /$ $5 \mathrm{~mL} ; 400 \mathrm{mg} / 5 \mathrm{~mL}$

Augmentin ES Augmentin powder for oral susp. $600 \mathrm{mg} / 5 \mathrm{~mL}$

Co-amoxiclav powder for oral suspension $125 \mathrm{mg} / 5 \mathrm{~mL} ; 250 \mathrm{mg} / 5 \mathrm{~mL} ; 400 \mathrm{mg} /$ $5 \mathrm{~mL}$

Maclivan powder for oral suspension

$250 \mathrm{mg} / 5 \mathrm{~mL} ; 400 \mathrm{mg} / 5 \mathrm{~mL}$

Cap. Doxy $100 \mathrm{mg}$

Cap. doxycycline $50 \mathrm{mg} ; 100 \mathrm{mg}$

Cap. Vibramycin Hyclate $100 \mathrm{mg}$

Tab. Doxylin $100 \mathrm{mg}$

Vibramycin-D 100 mg Dispersible tabs

Vibra-Tabs $100 \mathrm{mg}$

Doxycycline powder for susp. $25 \mathrm{mg} / 5 \mathrm{~mL}$

Vibramycin monohydrate powder for

susp. $25 \mathrm{mg} \cdot \mathrm{mL}^{-1}$

Vibramycin calcium syrup $50 \mathrm{mg} \cdot \mathrm{mL}^{-1}$
Cap.: store in a dry place, below $25^{\circ} \mathrm{C}$

Alcohol: no special recommendation

Powder for susp.: store in a dry place, below $25^{\circ} \mathrm{C}$

Reconstituted susp.: according to

manufacturer instructions, store in a

refrigerator $\left(2-8^{\circ} \mathrm{C}\right)$ or at room

temperature (below $25^{\circ} \mathrm{C}$ ) and use within

7-14 days ${ }^{\#}$; shake immediately prior

to use

Tab.: store in the original package in order to protect from moisture; store below $25^{\circ} \mathrm{C}$

Augmentin tab. supplied in an aluminium

pouch should be used within 30 days of opening the pouch

Powder for susp.: store in the original package in order to protect from moisture; store below $25^{\circ} \mathrm{C}$

Reconstituted susp.: according to manufacturer instructions, store in a refrigerator $\left(2-8^{\circ} \mathrm{C}\right)$ and use within $7-10$ days $^{\#}$

Cap., tab.: store in the original package in order to protect from light and moisture store below $25^{\circ} \mathrm{C}^{\#}$

Powder for susp.: store in the original package in order to protect from light and moisture; store below $25^{\circ} \mathrm{C}^{\#}$

Reconstituted susp.: store in the original package in order to protect from light and moisture; store below $25^{\circ} \mathrm{C}$ lup to $30^{\circ} \mathrm{C}$ according to manufacturer); use within 14 days from reconstitution; shake immediately prior to use

Syrup: store in the original package in order to protect from light and moisture store below $30^{\circ} \mathrm{C}$
Alcohol: no special recommendation

Skin photosensitivity: sunlight or ultraviole light exposure increases the risk of

photosensitivity; use skin protection and avoid prolonged exposure to sunlight and ultraviolet light; avoid use of tanning equipment.

Discontinue the treatment at first sign of skin erythema

Alcohol: ingestion may shorten the half-life of doxycycline and reduce its serum concentration; the combination should be avoided 


\begin{tabular}{|c|c|c|c|}
\hline Drug name & Common trade names in Europe & Storage conditions & Comments \\
\hline Minocycline & $\begin{array}{l}\text { Cap. minocycline } 50 \text { mg; } 100 \mathrm{mg} \\
\text { Cap. Minoclin } 100 \mathrm{mg} \\
\text { Tab. minocycline } 50 \mathrm{mg} ; 100 \mathrm{mg}\end{array}$ & $\begin{array}{l}\text { Cap., tab.: store in the original package in } \\
\text { order to protect from light; store below } \\
25^{\circ} \mathrm{C}\end{array}$ & $\begin{array}{l}\text { Skin photosensitivity: may cause } \\
\text { photosensitivity; use skin protection and } \\
\text { avoid prolonged exposure to sunlight and } \\
\text { ultraviolet light; avoid use of tanning } \\
\text { equipment } \\
\text { Discontinue the treatment if skin erythema } \\
\text { occurs } \\
\text { Alcohol: no special recommendation }\end{array}$ \\
\hline Cefuroxime & $\begin{array}{l}\text { Tab. Zinnat } 125 \mathrm{mg} ; 250 \mathrm{mg} \text {; } 500 \mathrm{mg} \\
\text { Tab. Cefuroxime } 250 \mathrm{mg} \\
\text { Zinnat powder for oral susp. } 125 \mathrm{mg} / 5 \mathrm{~mL} \text {; } \\
\quad 250 \mathrm{mg} / 5 \mathrm{~mL}\end{array}$ & $\begin{array}{l}\text { Tab. store in the original package in order } \\
\text { to protect from moisture; store below } 30^{\circ} \mathrm{C} \\
\text { Powder for suspension: store in the original } \\
\text { package, below } 30^{\circ} \mathrm{C} \\
\text { Reconstituted susp.: store in a refrigerator } \\
\left(2-8^{\circ} \mathrm{C}\right) \text {; do not freeze } \\
\text { After reconstitution, use the susp. within } \\
10 \text { days; shake the bottle vigorously } \\
\text { before the medication is taken }\end{array}$ & Alcohol: no special recommendation \\
\hline Cephalexin & $\begin{array}{l}\text { Cap. Cefovit } 250 \mathrm{mg} \text {; forte } 500 \mathrm{mg} \\
\text { Cap., tab. Cefalexin } 250 \mathrm{mg} ; 500 \mathrm{mg} \\
\text { Tab. Keflex } 250 \mathrm{mg} ; 500 \mathrm{mg} \\
\text { Cefovit powder for oral susp. } 125 \mathrm{mg} / 5 \mathrm{~mL} \text {; } \\
\text { Cefovit forte } 250 \mathrm{mg} / 5 \mathrm{~mL} \\
\text { Cefalexin granules for oral susp. } 125 \mathrm{mg} / \\
5 \mathrm{~mL} ; 250 \mathrm{mg} / 5 \mathrm{~mL} \\
\text { Keflex granules for oral susp. } 125 \mathrm{mg} / 5 \mathrm{~mL} \text {; } \\
\quad 250 \mathrm{mg} / 5 \mathrm{~mL}\end{array}$ & $\begin{array}{l}\text { Cap.: store in a dry place, below } 25^{\circ} \mathrm{C} \\
\text { Powder/granules for susp.: store in a dry } \\
\text { place, below } 25^{\circ} \mathrm{C} \\
\text { Reconstituted susp.: according to } \\
\text { manufacturer instructions, store in a } \\
\text { refrigerator }\left(2-8^{\circ} \mathrm{C}\right) \text { and use within } \\
10-14 \text { days }{ }^{\#} \text {; shake well before each use }\end{array}$ & Alcohol: no special recommendation \\
\hline SMX-TMP & $\begin{array}{l}\text { Caplets Diseptyl forte } 800 \mathrm{mg} / 160 \mathrm{mg} \\
\text { Tab. co-trimoxazole } 400 \mathrm{mg} / 80 \mathrm{mg} \\
\text { Tab. co-trimoxazole forte } 800 \mathrm{mg} / 160 \mathrm{mg} \\
\text { Tab. Septrin } 400 \mathrm{mg} / 80 \mathrm{mg} \\
\text { Tab. Septrin forte } 800 \mathrm{mg} / 160 \mathrm{mg} \\
\text { Susp. Diseptyl } 200 \mathrm{mg} / 40 \mathrm{mg} \text { in } 5 \mathrm{~mL} \\
\text { Co-trimoxazole paediatric susp. } 200 \mathrm{mg} / \\
\quad 40 \mathrm{mg} \text { in } 5 \mathrm{~mL} \\
\text { Co-trimoxazole adult susp. } 400 \mathrm{mg} / 80 \mathrm{mg} \\
\text { in } 5 \mathrm{~mL} \\
\text { Septrin paediatric susp. } 200 \mathrm{mg} / 40 \mathrm{mg} \text { in } \\
5 \mathrm{~mL} \\
\text { Septrin adult susp. } 400 \mathrm{mg} / 80 \mathrm{mg} \text { in } 5 \mathrm{~mL}\end{array}$ & $\begin{array}{l}\text { Susp. Store in a dark and dry place, below } \\
25^{\circ} \mathrm{C} \\
\text { Use within } 10 \text { days of opening } \# \text {. }\end{array}$ & $\begin{array}{l}\text { Skin photosensitivity: as been reported with } \\
\text { SMX-TMP; use with caution; use skin } \\
\text { protection and avoid prolonged exposure } \\
\text { to sunlight and ultraviolet light; avoid use } \\
\text { of tanning equipment } \\
\text { Discontinue the treatment if skin erythema } \\
\text { occurs } \\
\text { Alcohol: a disulfiram-like reaction (flushing, } \\
\text { sweating, palpitations and drowsiness) } \\
\text { may occur if alcohol (0.5-1 L of an } \\
\text { alcoholic drink e.g. beer) is ingested }\end{array}$ \\
\hline
\end{tabular}


Tab. Ciprodex 250 mg; 500 mg; 750 mg Tab. ciprofloxacin Teva 250 mg: 500 mg: $750 \mathrm{mg}$

Ciprofloxacin 100 mg; 250 mg; 500 mg: $750 \mathrm{mg}$ film-coated tab.

Tab. Ciproxin $500 \mathrm{mg}$

Ciproxin $250 \mathrm{mg} / 5 \mathrm{~mL}$, granules and solvent for oral susp.

Moxifloxacin

Tab. Megaxin $400 \mathrm{mg}$

Tab., film-coated Moxicloxacin $400 \mathrm{mg}$ Tab. Avelox $400 \mathrm{mg}$

Fluconazole

Itraconazole
Cap. Flucanol 50 mg; 100 mg; 150 mg; $200 \mathrm{mg}$

Cap. fluconazole Teva $150 \mathrm{mg}$

Cap. Trican 50 mg, 100 mg, 150 mg, 200 mg Cap. fluconazole/Azocan $50 \mathrm{mg}, 150 \mathrm{mg}$.

$$
200 \mathrm{mg}
$$

Fluconazole powder for oral susp. (Genus Pharmaceuticals) $50 \mathrm{mg} / 5 \mathrm{~mL}$

Diflucan powder for oral suspension

$10 \mathrm{mg} / \mathrm{mL} ; 40 \mathrm{mg} / \mathrm{mL}$

Cap. Itranol $100 \mathrm{mg}$

Cap. itraconazole $100 \mathrm{mg}$

Cap. Sporanox

Sporanox oral solution $10 \mathrm{mg} \cdot \mathrm{mL}^{-1}$

Itraconazole $10 \mathrm{mg} \cdot \mathrm{mL}^{-1}$ oral solution

\section{Storage conditions}

Tab. store in the original package, below $25^{\circ} \mathrm{C}$

Ciproxin: store the granules and solvent below $25^{\circ} \mathrm{C}$; protect the solvent from freezing; avoid inverted storage

The ready-to-use oral susp. lutilising the individual components) is stable only for 14 days when either stored in a refrigerator $\left(2-8^{\circ} \mathrm{C}\right)$ or at temperatures up to $30^{\circ} \mathrm{C}$; protect the reconstituted susp. from freezing

Tab.: store in the original package in order to protect from moisture; store below $25^{\circ} \mathrm{C}$

Cap.: store in a dry place below $25^{\circ} \mathrm{C}^{\#}$

Powder for susp.: store in a dry place, below $25^{\circ} \mathrm{C}$

Reconstituted susp. store in a refrigerator $\left(2-8^{\circ} \mathrm{C}\right)$ or at temperatures up to $30^{\circ} \mathrm{C}$ use within 14-28 days ${ }^{\#}$; protect the reconstituted susp. from freezing; shake well before administration

Cap.: store in the original package in order to protect from moisture; store below $25^{\circ} \mathrm{C}$ Sporanox cap.: up to $30^{\circ} \mathrm{C}$

Powder for susp.: store below $25^{\circ} \mathrm{C}$; use within 30 days of opening

\section{Comments}

Skin photosensitivity: ciprofloxacin has been shown to cause photosensitivity reactions: use skin protection and avoid prolonged exposure to sunlight and ultraviolet light; avoid use of tanning equipment

Discontinue the treatment if skin erythema occurs

Caffeine: ciprofloxacin has been shown to interfere with the metabolism of caffeine leading to increased caffeine

concentrations; patients consuming regular large quantities of caffeinated beverages may need to restrict caffeine intake if excessive cardiac or central nervous system stimulation occurs; the effect of this interaction is greater in females

Skin photosensitivity: quinolones have been shown to cause photosensitivity reactions in patients; use skin protection and avoid prolonged exposure to sunlight and ultraviolet light; avoid use of tanning equipment

Discontinue the treatment if skin erythema occurs

Alcohol: no special recommendation

Skin photosensitivity: uncommon $(\leqslant 2 \%)$; case reports have been described

Use skin protection and avoid prolonged exposure to sunlight and ultraviolet light; avoid use of tanning equipment

Discontinue the treatment if skin erythema occurs

Alcohol: no special recommendation 


\section{Drug name}

\section{Expectorants and cough}

\section{suppressants}

Acetylcysteine

Reolin effervescent tablets $200 \mathrm{mg}$

Siran 200 mg effervescent tablets

Sachet acetylcysteine $200 \mathrm{mg}$ powder for oral solution

\section{Guaifenesin}

Resyl syrup $100 \mathrm{mg} / 5 \mathrm{~mL}$ (contains 6\% alcohol by volumel

Benylin syrup for children's chesty coughs $50 \mathrm{mg} / 5 \mathrm{~mL}$

Benylin syrup Mucus Cough Max honey and lemon flavour $100 \mathrm{mg} / 5 \mathrm{~mL}$ (contains $4.7 \%$ alcohol by volume

Oral solution Benylin Mucus Cough Max menthol flavour $100 \mathrm{mg} / 5 \mathrm{~mL}$ (contains $4.7 \%$ alcohol by volume)

Boots chesty cough relief $100 \mathrm{mg} / 5 \mathrm{~mL}$ oral solution

Boots chesty cough syrup 6 years plus (contains alcohol)

Boots mucus cough relief $100 \mathrm{mg} / 5 \mathrm{~mL}$ oral solution

Covonia chesty cough SF syrup

Robitussin chesty cough medicine $100 \mathrm{mg} /$ $5 \mathrm{~mL}^{-1}$ oral solution (contains $2.7 \% \mathrm{v} / \mathrm{v}$ alcohol)

Lemsip cough for chesty cough $50 \mathrm{mg} / 5 \mathrm{~mL}$ oral solution
Effervescent tablets: store in the original package in order to protect from

moisture; store below $25^{\circ} \mathrm{C}$; close the tube immediately after taking out the tablet

After dissolving the tablet, it must be used immediately

Reolin: use within 2 years after the first opening or until the expiry date

Siran: use within 4 weeks after the first opening

Powder for oral solution: store in the original package in order to protect from moisture

Reconstituted solution: the product must be used immediately

Syrup: store in the original package, below $25^{\circ} \mathrm{C}$

Resyl: store below $30^{\circ} \mathrm{C}$; use within

6 months of opening

Benylin honey and lemon flavour: use within 6 months of opening

Oral solution: store below $25^{\circ} \mathrm{C}$

Benylin menthol flavour: store in the original container to protect from light and use within 4 weeks of opening
Alcohol: no special recommendation

Alcohol: some products contain alcohol; therefore, these formulations can emphasise the effect of sedatives

(including alcohol) and myorelaxants

Avoid concurrent use or use caution when motor skills are required 
Other oral medications Prednisone

Tab. prednisone $1 \mathrm{mg} ; 5 \mathrm{mg} ; 20 \mathrm{mg}$ Modified-release tab. Lodotra $1 \mathrm{mg}$ :

$2 \mathrm{mg} ; 5 \mathrm{mg}$

Prednisolone

Proton pump inhibitors Omeprazole
Tab. Pevanti $2.5 \mathrm{mg} ; 5 \mathrm{mg} ; 10 \mathrm{mg}$ : $20 \mathrm{mg} ; 25 \mathrm{mg}$

Tab. prednisolone $1 \mathrm{mg}, 2.5 \mathrm{mg} ; 5 \mathrm{mg}$; $10 \mathrm{mg} ; 20 \mathrm{mg} ; 25 \mathrm{mg} ; 30 \mathrm{mg}$

Tab. prednisolone gastro-resistant $1 \mathrm{mg}$ : $2.5 \mathrm{mg}$; $5 \mathrm{mg}$

Soluble tab. prednisolone $5 \mathrm{mg}$

Danalone syrup $15 \mathrm{mg} / 5 \mathrm{~mL}$ (contains

alcohol

Prednisolone Dompe $1 \mathrm{mg} \cdot \mathrm{mL}^{-1}$ oral solution (single-dose containers)

Prednisolone $10 \mathrm{mg} \cdot \mathrm{mL}^{-1}$ oral solution

Caplets Omepradex $10 \mathrm{mg} ; 20 \mathrm{mg} ; 40 \mathrm{mg}$ Caplets Omepradex-Z $20 \mathrm{mg}$

Cap. Losec $20 \mathrm{mg}$ (Israel)

Cap. Omepra 10 mg; 20 mg; 40 mg

Cap. Omeprix $20 \mathrm{mg}$

Cap. Losec 10 mg; 20 mg; 40 mg (Europe) Cap. Mepradec gastro-resistant 10, $20 \mathrm{mg}$ Cap. Omeprazole gastro-resistant $10 \mathrm{mg}$;

$20 \mathrm{mg} ; 40 \mathrm{mg}$

Cap. Prenome $10 \mathrm{mg} ; 20 \mathrm{mg} ; 40 \mathrm{mg}$

Cap. Omeprazole $10 \mathrm{mg} ; 20 \mathrm{mg} ; 40 \mathrm{mg}$

Tab. Omeprazole Gastro-resistant $10 \mathrm{mg}$ :

$20 \mathrm{mg}$; $40 \mathrm{mg}$

Pyrocalm Control $20 \mathrm{mg}$ gastro-resistant tablets
Tab.: store in a dark and dry place, below $25^{\circ} \mathrm{C}$

Tab. prednisone $1 \mathrm{mg}$ : use within 2 months of opening (but not after the expiry date) Lodotra: store below $25^{\circ} \mathrm{C}$ and use within 14 weeks of opening (but not after the expiry date)

Tab. (also gastro-resistant and soluble tab.): store in the original package in order to protect from light and moisture, below $25^{\circ} \mathrm{C}$

Pevanti: use within 6 months of opening (but not after the expiry date)

Syrup: store below $25^{\circ} \mathrm{C}$ but not in the refrigerator; close firmly, and prevent penetration of air and moisture

Dompe: before opening, store in the original package; store below $30^{\circ} \mathrm{C}$

Once opened, the container must be discarded once the dose is removed

Prednisolone $10 \mathrm{mg} \cdot \mathrm{mL}^{-1}$ : keep the container in the outer carton in order to protect from light

Before opening, store in a refrigerator $\left(2-8^{\circ} \mathrm{C}\right)$

Once opened, store below $25^{\circ} \mathrm{C}$ and use within 3 months

Caplets: store in the original package, below $25^{\circ} \mathrm{C}$

Cap., tab.: store below $25^{\circ} \mathrm{C}$

Store in the original package in order to protect from moisture, below $25-30^{\circ} \mathrm{C}$ and use within 3 months of opening of the bottle
Alcohol: no special recommendation

Alcohol: some products contain alcohol; avoid concurrent use of ethanol with these formulations or use caution when motor skills are required
Skin photosensitivity: has been described but is rare $l \leqslant 0.1 \%$

Alcohol: no special recommendation 


\section{Drug name}

Esomeprazole

Lansoprazole

Pantoprazole

$\mathrm{H} 2$ blockers

Famotidine

Ranitidine

\section{Common trade names in Europe}

Tab. esomeprazole Inovamed $20 \mathrm{mg} ; 40 \mathrm{mg}$ Tab. Nexium 20 mg; 40 mg

Tab. esomeprazole gastro-resistant $20 \mathrm{mg}$; $40 \mathrm{mg}$

Cap. Emozul gastro-resistant 20 mg, $40 \mathrm{mg}$ Cap. esomeprazole gastro-resistant $20 \mathrm{mg}$;

$$
40 \mathrm{mg}
$$

Ventra gastro-resistant capsules $20 \mathrm{mg}$ : $40 \mathrm{mg}$

Sachet Nexium $10 \mathrm{mg}$ gastro-resistant granules for oral susp.

Cap. lansoprazole $15 \mathrm{mg} ; 30 \mathrm{mg}$

Cap. Lanton $15 \mathrm{mg} ; 30 \mathrm{mg}$

Cap. lansoprazole gastro-resistant $15 \mathrm{mg}$; $30 \mathrm{mg}$

Orodispersible tab. lansoprazole $15 \mathrm{mg}$;

$$
30 \mathrm{mg}
$$

Zoton Fas-Tab 15 mg; $30 \mathrm{mg}$

Tab. Contrololc $20 \mathrm{mg} ; 40 \mathrm{mg}$

Pantoloc Control 20 mg gastro-resistant

tablets

Tab. Pantoprazole gastro-resistant $20 \mathrm{mg}$; $40 \mathrm{mg}$

Tab. famotidine Teva $20 \mathrm{mg}$; $40 \mathrm{mg}$

Tab. Famo 20 mg; $40 \mathrm{mg}$

Tab. Gastro $10 \mathrm{mg} ; 20 \mathrm{mg} ; 40 \mathrm{mg}$

Tab. Pepcid $20 \mathrm{mg}$; $40 \mathrm{mg}$

Pepcid powder for oral susp. $40 \mathrm{mg} / 5 \mathrm{~mL}$

Tab. Zaridex $150 \mathrm{mg} ; 300 \mathrm{mg}$

Tab. Ranitidine film-coated $150 \mathrm{mg} ; 300 \mathrm{mg}$

Tab. Zantac 75 mg; 150 mg; $300 \mathrm{mg}$

Zantac syrup $150 \mathrm{mg} / 10 \mathrm{~mL}$ (contains $\sim 7.5 \% \mathrm{w} / \mathrm{v}$ alcohol]

Ranitidine $150 \mathrm{mg} / 10 \mathrm{~mL}$ oral solution

(contains $~ 8 \% \mathrm{w} / \mathrm{v}$ alcohol)

Ranitidine $30 \mathrm{mg} \cdot \mathrm{mL}^{-1}$ oral solution

(contains $\sim 7.5 \% \mathrm{w} / \mathrm{v}$ alcohol)

\section{Storage conditions}

Tab., cap.: store in the original package in order to protect from moisture

Store below $25-30^{\circ} \mathrm{C}^{\#}$ and use within

3-6 months after first opening of the bottle $^{\#}$

Granules for oral susp.: use within $30 \mathrm{~min}$ after reconstitution

Cap., tab.: store in the original package in order to protect from light and moisture: store below $25^{\circ} \mathrm{C}$

Use within 2 months to 100 days after first opening of the bottle

Tab. store in the original package in order to protect from moisture; store below $25^{\circ} \mathrm{C}$

Use within 6 months after first opening of the bottle

Tab. store in the original package in order to protect from light and moisture; store below $25^{\circ} \mathrm{C}$

Powder for susp.: store in the original package at $25^{\circ} \mathrm{C}$; excursions permitted to $15-30^{\circ} \mathrm{C}$

Reconstituted susp.: after reconstitution,

use the suspension within 30 days: protect from freezing

Tab.: store in the original package below $25^{\circ} \mathrm{C}$

Syrup: store below $25^{\circ} \mathrm{C}$ and use within 28 days of opening

Oral solution: store in original carton/bottle in order to protect from light; store below $25^{\circ} \mathrm{C}$

\section{Comments}

Skin photosensitivity: has been described in

the literature but is rare $(\leqslant 0.1 \%)$

Alcohol: no special recommendation

Skin photosensitivity: has been described in

the literature but is rare $\{\leqslant 0.1 \%$ )

Alcohol: no special recommendation

Skin photosensitivity: has been described in the literature (but the frequency cannot

be estimated from the available data);

use with caution

Alcohol: no special recommendation

Alcohol: no special recommendation

Alcohol: co-ingestion of alcohol (1.5-2 drinks) while on ranitidine may result in higher blood alcohol concentrations, although the clinical significance is uncertain

In addition, some products contain alcohol; avoid concurrent use of ethanol with

these formulations or use caution when motor skills are required 


\section{Drug name}

Antacids

Aluminium hydroxide,

magnesium hydroxide and dimethicone/simethicone

Calcium carbonate

Calcium carbonate and magnesium carbonate

Calcium carbonate, sodium bicarbonate and sodium alginate

\section{Bronchodilators: inhalers and} solution

Salbutamol MDI

Common trade names in Europe

Storage conditions

\section{Comments}

Maalox Plus chewable tablets $1200 \mathrm{mg}$ magnesium hydroxide, $200 \mathrm{mg}$ hydrated aluminium oxide and $25 \mathrm{mg}$ dimethicone in a tablet)

Maalox Plus oral susp. $1225 \mathrm{mg}$ aluminium hydroxide, $200 \mathrm{mg}$ magnesium hydroxide and $25 \mathrm{mg}$ simethicone in $5 \mathrm{~mL}$

Chewable tab. Tums

Chewable tab. N-Zarevet

Chewable tab.

Chewable tab. Rennie

Chewable tab. Rolaids

Rolaids mint liquid $1550 \mathrm{mg}$ calcium carbonate and $110 \mathrm{mg}$ magnesium hydroxide in $5 \mathrm{~mL}$ )

Chewable tab. Gaviscon

Gaviscon peppermint liquid

Gaviscon liquid sachets mint flavour (500 mg sodium alginate, $267 \mathrm{mg}$ sodium bicarbonate and $160 \mathrm{mg}$ calcium carbonate per $10-\mathrm{mL}$ dose

Ventolin inhaler CFC-Free $100 \mu \mathrm{g}$ per dose Salbutrim CFC-free inhaler $100 \mu \mathrm{g}$ per dose

Easyhaler Salbutamol $100 \mu \mathrm{g}$ per dose $200 \mu \mathrm{g}$ per dose

Salamol Easi-Breathe $100 \mu \mathrm{g}$ per dose Salbulin MDPI Novolizer
Tab.: store in the original package, below $25^{\circ} \mathrm{C}$

Oral susp.: store below $25^{\circ} \mathrm{C}$ and use within 28 days of opening; shake well before administration

Chewable tab.: store in the original

package, below $25^{\circ} \mathrm{C}$

$\mathrm{N}$-Zarevet: use within 12 months after first opening of the bottle

Chewable tab.: store in the original

package, below $25^{\circ} \mathrm{C}$

Liquid: do not freeze

Chewable tab.: store in the original package in order to protect from moisture; below $25-30^{\circ} \mathrm{C}^{\#}$

Liquid: store in the original package, below $25-30^{\circ} \mathrm{C}$ laccording to manufacturer instructions) and use within 6 months of opening

Liquid sachet: store in the original package, below $25^{\circ} \mathrm{C}$; discard any unused contents

Ventolin, Salbutrim: store below $30^{\circ} \mathrm{C}$; protect from frost and direct sunlight If the inhaler gets very cold, take the metal container out of the plastic case and warm it in your hands for a few minutes; do not use anything else to warm it up

Easyhaler: store in a dry place, at a temperature below $25^{\circ} \mathrm{C}$; use within 6 months after first opening of foil pouch Salbulin: store below $30^{\circ} \mathrm{C}$; use within 6 months after first opening the container

Alcohol: no special recommendation

Alcohol: no special recommendation

Alcohol: no special recommendation

Alcohol: no special recommendation

Alcohol: no special recommendation 


\begin{tabular}{|c|c|c|c|}
\hline Drug name & Common trade names in Europe & Storage conditions & Comments \\
\hline Ipratropium MDI & MDI Atrovent $20 \mu \mathrm{g}$ per dose & $\begin{array}{l}\text { MDI: store below } 25^{\circ} \mathrm{C} \text { (Europe) or } 30^{\circ} \mathrm{C} \\
\text { (Israel); protect from frost and direct } \\
\text { sunlight; do not expose to temperature } \\
>50^{\circ} \mathrm{C}\end{array}$ & Alcohol: no special recommendation \\
\hline \multirow[t]{3}{*}{ Salbutamol (solution) } & $\begin{array}{l}\text { Ventolin respirator solution } 5 \mathrm{mg} \cdot \mathrm{mL}^{-1} \\
(0.5 \% \mathrm{w} / \mathrm{v})\end{array}$ & $\begin{array}{l}\text { Ventolin respirator solution: store below } \\
25-30^{\circ} \mathrm{C}^{\#} ; \text { protect from light; discard any } \\
\text { contents remaining } 1 \text { month after opening } \\
\text { the bottle } \\
\text { A fresh solution should be prepared before } \\
\text { each usage }\end{array}$ & Alcohol: no special recommendation \\
\hline & $\begin{array}{l}\text { Ventolin Nebules } 2.5 \mathrm{mg} / 2.5 \mathrm{~mL}(0.1 \% \mathrm{w} / \mathrm{v}) \text {, } \\
5 \mathrm{mg} / 2.5 \mathrm{~mL}(0.2 \% \mathrm{w} / \mathrm{v}) \\
\text { Ampules Salbutamol } 2.5 \mathrm{mg} / 2.5 \mathrm{~mL} \\
\text { nebuliser solution; } 5 \mathrm{mg} / 2.5 \mathrm{~mL}\end{array}$ & $\begin{array}{l}\text { Ventolin Nebules, Ampules Salbutamol: } \\
\text { store below } 25-30^{\circ} \mathrm{C}^{\#} \text {; protect from light } \\
\text { after removal from the foil overwrap } \\
\text { pouch }\end{array}$ & \\
\hline & & $\begin{array}{l}\text { Use nebules } 3 \text { months after removal from } \\
\text { the foil pouch; use immediately after first } \\
\text { opening of the ampule and discard any } \\
\text { unused contents }\end{array}$ & \\
\hline \multirow[t]{6}{*}{ Ipratropium (solution) } & Aerovent respirator solution $0.25 \mathrm{mg} \cdot \mathrm{mL}^{-1}$ & $\begin{array}{l}\text { Respirator solution: store below } 25^{\circ} \mathrm{C} \text {; do } \\
\text { not freeze }\end{array}$ & Alcohol: no special recommendation \\
\hline & & $\begin{array}{l}\text { Discard any contents remaining } 1 \text { month } \\
\text { after opening the bottle }\end{array}$ & \\
\hline & & $\begin{array}{l}\text { A fresh solution should be prepared before } \\
\text { each usage }\end{array}$ & \\
\hline & $\begin{array}{l}\text { Atrovent } 250 \mathrm{UDVs}, 1 \mathrm{~mL} \text {; Atrovent UDVs, } \\
2 \mathrm{~mL}-0.25 \mathrm{mg} \cdot \mathrm{mL}^{-1} \text { vials }\end{array}$ & $\begin{array}{l}\text { Atrovent } 250 \text { UDVs, Atrovent UDVs, Ampules } \\
\text { Ipratropium bromide: keep the vials in }\end{array}$ & \\
\hline & Ampules ipratropium bromide $250 \mu \mathrm{g} / 1 \mathrm{~mL}$ & the outer carton; store below $25^{\circ} \mathrm{C}$ & \\
\hline & $\begin{array}{l}\text { nebuliser solution; } 500 \mu \mathrm{g} / 2 \mathrm{~mL} \text { nebuliser } \\
\text { solution }\end{array}$ & $\begin{array}{l}\text { Use immediately after first opening of the } \\
\text { ampule and discard any unused contents }\end{array}$ & \\
\hline \multicolumn{4}{|l|}{ Other inhaled medications } \\
\hline \multirow[t]{3}{*}{$\begin{array}{l}\text { Isotonic saline (sodium } \\
\text { chloride } 0.9 \% \mathrm{w} / \mathrm{v} \text { ) }\end{array}$} & $\begin{array}{l}\text { Ampules sodium chloride } 0.9 \% \text { Fresenius } \\
5 \mathrm{~mL} ; 10 \mathrm{~mL} ; 20 \mathrm{~mL} \text { per ampule }\end{array}$ & $\begin{array}{l}\text { Ampules: store below } 25^{\circ} \mathrm{C} \text {; do not } \\
\text { refrigerate or freeze }\end{array}$ & Alcohol: no special recommendation \\
\hline & $\begin{array}{l}\text { Saline nebuliser solution Arrow } 2.5 \mathrm{~mL} \text { per } \\
\text { ampule }\end{array}$ & $\begin{array}{l}\text { Saline nebuliser solution } \\
\text { Strips of } 10 \text { ampules are overwrapped in an }\end{array}$ & \\
\hline & Saline Steripoules $2.5 \mathrm{~mL}$ & $\begin{array}{l}\text { aluminium foil pack; ampules removed } \\
\text { from the foil overwrap should be used } \\
\text { within } 90 \text { days }\end{array}$ & \\
\hline \multirow[t]{3}{*}{$\begin{array}{l}\text { Hypertonic saline (sodium } \\
\text { chloride } 3 \%, 6 \%, 7 \% \mathrm{w} / \mathrm{v} \text { ) }\end{array}$} & $\begin{array}{l}\text { INH Solution MucoClear (sodium chloride) } \\
3 \%, 4 \mathrm{~mL} \text { per ampule }\end{array}$ & $\begin{array}{l}\text { MucoClear: store below } 25^{\circ} \mathrm{C} \text {; do not } \\
\text { refrigerate or freeze }\end{array}$ & Alcohol: no special recommendation \\
\hline & $\begin{array}{l}\text { INH Solution MucoClear (sodium chloride) } \\
6 \%, 4 \mathrm{~mL} \text { per ampule }\end{array}$ & & \\
\hline & $\begin{array}{l}\text { INH Solution PulmoSal 7\%, }(\mathrm{pH}+) 4 \mathrm{~mL} \\
\text { per vial }\end{array}$ & $\begin{array}{l}\text { Pulmosal: store at room temperature, } \\
15-30^{\circ} \mathrm{C} \text {; avoid excessive heat and protect } \\
\text { from freezing }\end{array}$ & \\
\hline
\end{tabular}


TABLE 3 Continued

\section{Drug name \\ Inhaled antimicrobials}

CMS

Tobramycin

\section{Common trade names in Europe}

Vial Coliracin 1000000 units per vial Vial CMS $1000000 \mathrm{IU}$ powder for solution for injection

Vial Colomycin 1000000 IU, 2 million IU

Promixin, 1000000 IU powder for nebuliser solution

Colobreathe 1662500 IU inhalation powder hard capsules ( 125 mg CMS)

Vial tobramycin $40 \mathrm{mg} \cdot \mathrm{mL}^{-1}$ solution for injection

Vial Nebcin injection $40 \mathrm{mg} \cdot \mathrm{mL}^{-1}$

Bramitob $300 \mathrm{mg} / 4 \mathrm{~mL}$ nebuliser solution, single-dose container

TOBI Podhaler $28 \mathrm{mg}$ per capsule inhalation powder, hard capsules

TOBI $300 \mathrm{mg} / 5 \mathrm{~mL}$ nebuliser solution, single-use ampule

TOBI Podhaler $28 \mathrm{mg}$ per capsule inhalation powder
Storage conditions

Vial: store below $25^{\circ} \mathrm{C}$; protect from light Use immediately after reconstitution with $0.9 \%$ sodium chloride; solutions may be used within $24 \mathrm{~h}$ when stored in a refrigerator $\left(2-8^{\circ} \mathrm{C}\right)$

Colobreathe: store in the original package until immediately before use in order to protect from moisture; store below $25^{\circ} \mathrm{C}$

Vial for injection: store in the outer carton in order to protect from light; store below $25^{\circ} \mathrm{C}$

Use immediately after reconstitution with $0.9 \%$ sodium chloride

Solutions may be used within $24 \mathrm{~h}$ when stored in a refrigerator $\left(2-8^{\circ} \mathrm{C}\right)$

A fresh solution should be prepared before each usage

Ready-to-use nebuliser solution: store in the original package in order to protect from light and moisture; store in a refrigerator $\left(2-8^{\circ} \mathrm{C}\right)$; do not freeze

The contents of the whole ampule should be used directly after opening; opened ampules should never be stored for re-use

TOBI pouch, Tymbrineb foil pouch, Tobramycin pouch (intact or opened); may be stored at room temperature lup to $25^{\circ} \mathrm{C}$ ) for up to 28 days

Bramitob bags (intact or opened) may be stored at room temperature (up to $25^{\circ} \mathrm{C}$ ) for up to 3 months

Vantobra pouch (intact or opened) may be stored at room temperature (up to $25^{\circ} \mathrm{C}$ ) for up to 4 weeks

Capsules for inhalation: TOBI Podhaler capsules must always be stored in the blister to protect from moisture and only removed immediately before use; store below $30^{\circ} \mathrm{C}$

Podhaler device: store the inhaler in its

tightly closed case when not in use; each Podhaler device and its case are used for 7 days and then discarded and replaced
Comments

Alcohol: no special recommendation

Alcohol: no special recommendation 


\section{TABLE 3 Continued}

\begin{tabular}{|c|c|c|c|}
\hline Drug name & Common trade names in Europe & Storage conditions & Comments \\
\hline Gentamicin & $\begin{array}{l}\text { Ampule gentamicin B. Braun } 1 \mathrm{mg} \cdot \mathrm{mL}^{-1} \text {; } \\
3 \mathrm{mg} \cdot \mathrm{mL}^{-1} \text { solution for infusion } \\
\text { Ampule gentamicin } 10 \mathrm{mg} \cdot \mathrm{mL}^{-1} \text { solution } \\
\text { Ampule Genticin } 40 \mathrm{mg} \cdot \mathrm{mL}^{-1} \text { injectable } \\
\text { Ampule Cidomycin } 80 \mathrm{mg} / 2 \mathrm{~mL} \text { solution for } \\
\text { injection }\end{array}$ & $\begin{array}{l}\text { Ampules for injection: store in the outer } \\
\text { carton in order to protect from light; } \\
\text { store below } 25^{\circ} \mathrm{C} \text {; use immediately after } \\
\text { reconstitution with } 0.9 \% \text { sodium chloride; } \\
\text { a fresh solution should be prepared } \\
\text { before each usage }\end{array}$ & Alcohol: no special recommendation \\
\hline
\end{tabular}

Cap: capsules; tab: tablets: susp.: suspension; SF: sugar free; SR: sustained release; SMX: sulfamethoxazole; TMP: trimethoprim; MDI: metered-dose inhaler; CFC: chlorofluorocarbon;

CMS: colistimethate sodium." : see leaflet, as different instructions for different manufacturers [23]. 
How can people with bronchiectasis maintain regular treatment when in transport?

Statements considered:

- It is advised that airway clearance and inhalations be performed while waiting at airports before and after flights. This is best planned ahead and checked with the airport for the best place to do this (77\% agreement).

- While it is not advised to take cough suppressants for bronchiectasis, it may be considered for long flights where a cough may be disturbing to other passengers (35\% agreement).

Some patients may want to avoid coughing and having to clear secretions during flights (or long travel by bus or train). In these cases, airway clearance may best be performed before and after flights. Since most airports may not have private facilities, practicing airway clearance at the airport should be planned ahead. Although no evidence exists on safety of cough suppressants, they are ill advised in bronchiectasis, and cannot be recommended, even during flights: $65 \%$ of experts specifically advised against the use of cough suppressants.

\section{Do people with bronchiectasis need to prepare and carry certain documents?}

Recommendations:

12) It is advised that people with bronchiectasis carry documentation from their last clinic/hospitalisation visit, translated into English and preferably also into the language of the country of destination ( $81 \%$ agreement).

13) A document for travel may be prepared and should include: patient's health status, allergies, chronic bacterial infections, regular medications and devices used regularly, and recommended medications during exacerbations (100\% agreement).

14) It is advised that people with bronchiectasis carry a translation of a disability card (such as a European Union disability parking card) if eligible and where available ( $84 \%$ agreement).

Other statement considered:

- When travelling in a guided tour, it is advised that people with bronchiectasis should notify the travel company of their condition (69\% agreement).

Documentation may be required for airport security staff and customs officials regarding medical equipment, but also for medical professionals in case of need. A recommended template for such documentation adapted from Hirche et al. [6] is provided in the supplement. The need to notify the travel company would depend on the severity of the disease and need for supplemental oxygen or disability. Likewise, it is advisable to check for custom requirements regarding medication and technical equipment with airport or custom authorities or travel agencies in advance. During guided tours, patients may need special consideration regarding the time and place for performing daily treatments and may wish to notify the guided tour organisers.

\section{What are the oxygen requirements on the flight and at the travel destination?}

Recommendations:

15) Oxygen requirements during commercial flights should be predicted before the flight $(100 \%$ agreement).

16) When planning travel to destinations between 2000 and $3050 \mathrm{~m}$, considerations as for commercial flights should be made ( $92 \%$ agreement).

Other statements considered:

- In people with an $\mathrm{FEV}_{1}<55 \%$ or oxygen saturation $<93 \%$ at ambient air, a hypoxic challenge test should be performed (77\% agreement).

- In people with $\mathrm{FEV}_{1}<1.5 \mathrm{l}$, hypoxia inhalation test should be performed (56\% disagreed)

In commercial flights, cabin air pressure is similar to $2000 \mathrm{~m}$ elevation; therefore conditions may aggravate hypoxemia in people with chronic lung conditions. Prediction of hypoxemia during flight may be advised for people with low lung capacity not already using oxygen supplementation, and supplemental oxygen prescribed if predicted arterial oxygen pressure is below $50 \mathrm{mmHg}$ [10]. In some countries the hypoxia challenge test is not widely available; in such circumstances, the prediction of hypoxaemia at cabin altitude using equations is possible (table 2). For patients already using oxygen, it is advised to increase the flow. It is always necessary to notify the airline company in advance regarding oxygen requirements during flight. Information regarding air travel for people with chronic lung diseases is available at the ELF website: www. europeanlung.org/en/lung-disease-and-information/air-travel/ and www.europeanlung.org/assets/files/en/ publications/air-travel-web.pdf (available in 18 languages).

How else can people with bronchiectasis be prepared to travel?

Recommendations:

17) It is recommended that people with bronchiectasis seek advice for travellers and follow recommended immunisations for the destination (100\% agreement). 
18) Recommended medications while travelling (such as for the prevention of malaria) should be checked for interactions with regular treatments and with treatments during exacerbations (100\% agreement).

19) It is recommended that people with bronchiectasis should be stable prior to travelling, if symptoms typical for an exacerbation develop shortly before travelling, treatment should be started and travel postponed if possible ( $96 \%$ agreement).

Other statement considered:

- People with severe bronchiectasis and chronic Pseudomonas aeruginosa infection may be advised to receive treatment with an intravenous antibiotic course shortly before travelling to prevent an exacerbation while away (50\% agreement).

When travelling to areas endemic for infectious diseases, people with bronchiectasis should consult expert advice and/or travel clinic healthcare workers regarding immunisations and medications for preventing infections. In people with bronchiectasis secondary to a primary immune deficiency, there is a need to consider both the safety of live attenuated vaccines (yellow fever vaccine for example) [24], and the efficacy of vaccinations. Mefloquine for the prevention of malaria has the potential to elongate the QT-interval, and may increase the risk for cardiac arrhythmias especially if combined with fluoroquinolones or azithromycin. Some patients with chronic Pseudomonas infection feel better for several weeks after a course of anti-pseudomonal antibiotic (intravenous or oral). In very certain cases of people with frequent exacerbations, treatment with such an antibiotic course may be considered before travelling to prevent an exacerbation, but there is no evidence to recommend this, with the concern for causing an emergence of resistant strains with unnecessary antibiotic treatment.

\section{What kind of activities can people with bronchiectasis engage in while travelling and what} precautions are recommended?

Recommendations:

20) It is recommended that people with bronchiectasis should use sun protection while using medications that increase photosensitivity, such as ciprofloxacin and doxycycline (100\% agreement).

21) It is recommended that people with bronchiectasis take measures to avoid dehydration while in a hot climate (100\% agreement).

22) It is advised that people with bronchiectasis maintain general measures of hygiene to prevent cross-infection, such as hand hygiene in crowded places $(88 \%)$.

23) It may be safe for people with bronchiectasis to SCUBA dive if they are asymptomatic (no sputum or shortness of breath at the time of diving), do not have cystic bronchiectasis, and lung function is normal $\left(\mathrm{FEV}_{1}\right.$ and peak expiratory flow should both be $>80 \%, \mathrm{FEV}_{1} /$ forced vital capacity $\left.>75 \%\right) \quad(85 \%$ agreement).

Other statement considered:

- It is recommended that all people with bronchiectasis refrain from SCUBA diving (35\% agreement).

Many people travel for leisure purposes, during which time they engage in activities, including sports, to which they may be unaccustomed to. Staying and performing strenuous activities, such as hiking, in hot climates carries a risk of dehydration, which is to be avoided in people with bronchiectasis (as hydration is important for mucus clearance). In fact, as a general recommendation, patients with bronchiectasis should avoid dehydration at all times. People with bronchiectasis who take medications which cause photosensitivity, such as ciprofloxacin and doxycycline (table 3) should be advised to use measures for sun protection and avoidance of direct sun exposure. Likewise, interaction with alcoholic beverages should be noted, as in some cases alcohol consumption may be increased during vacations. Staying in crowded places carries a risk of acquiring airborne infections; it is advised to use hand hygiene and avoid sharing items such as blankets, drinking equipment, silverware and earphones. There is no evidence to support the efficacy of wearing face masks. Due to the inconvenience and possibly stigma associated with wearing face masks [5], their use is not recommended.

SCUBA diving is an increasingly popular recreational activity among individuals, including people with chronic conditions and older age $[25,26]$. During underwater diving, ambient pressure increases by $1 \mathrm{~atm}$ $(100 \mathrm{kPa})$ for every $10 \mathrm{~m}$ descended. Gas volumes change with the depth of diving, compressing during descent and expanding during ascent. The partial pressure of gases increases with the increase in hydrostatic pressure. Nitrogen, an inert gas, dissolves in tissues at depth and comes out of solution on ascent. Another aspect of diving is that the work of breathing increases during diving due to increased gas density, increased hydrostatic pressure, and altered respiratory mechanics (increased dead space and resistance to breathing caused by SCUBA breathing apparatus). The risks associated with diving include: 1) barotrauma caused by expansion of gas-filled spaces during ascent; 2) Compression of the lungs during descent which can cause alveolar exudation and haemorrhage; and 3) Expansion of the lungs during ascent that can cause tearing of structures and lead to pneumothorax, pneumomediastinum and arterial gas embolism. In bronchiectasis, mucus in airways or lung cysts can cause air trapping which may be 
associated with an elevated risk of barotrauma. Recommendations on medical fitness for diving [7] advise against diving in people with pulmonary cysts or bullae, in people with asthma unless they are asymptomatic with a normal spirometry, and in people with CF and pulmonary involvement. Similar recommendations are given by the South Pacific Underwater Medicine Society (www.spums.org.au/ content/spums-full-medical-0) while other national diving recommendations recommend against diving in people with bronchiectasis [11]. However, due to the large heterogeneity of bronchiectasis, only $35 \%$ of bronchiectasis experts in our survey answered that all people with bronchiectasis should refrain from SCUBA diving. The majority assumed it may be safe for people with mild bronchiectasis to dive provided they are asymptomatic, with normal spirometry and no lung cysts evident on computed tomography $(85 \%$ agreement).

Although it may be intuitively tempting to advise limiting diving to shallow depths for people with bronchiectasis, there is no physiological basis to support this recommendation: any change in depth poses a similar risk, and most diving-related injuries occur at relatively shallow depths [7, 27].

Many other recreational sports and activities (SCUBA diving included, but also water surfing, hiking, skiing) require levels of exertion that some people with chronic medical conditions may be unaccustomed to: one paper estimated exercise during recreational diving to equal 7 metabolic equivalents of task [28]. It is always prudent for people with bronchiectasis and advising physicians to be aware of functional limitations. If in doubt, a formal exercise test may be performed when planning sports activities.

\section{Where should people with bronchiectasis get help if they become unwell while travelling?}

Recommendations

24) Prior to travel, people with bronchiectasis should be advised on increasing airway clearance if suffering an exacerbation while away (96\% agreement).

25) Prior to travel, people with bronchiectasis should be advised when to take antibiotics, including a recommendation for an oral antibiotic, dose and duration (100\% agreement).

26) People with bronchiectasis should be advised when and where to seek medical care at their destination (88\% agreement).

Exacerbations are periods of time when an increase in symptoms (sputum purulence and quantity, dyspnoea, malaise, fever) occur $[16,29]$. The aetiology of pulmonary exacerbations is most often presumed to be inflammatory/infectious, although not always known, and some patients are more prone to exacerbations than others [16]. Current guidelines recommend treating pulmonary exacerbations of bronchiectasis with increasing airway clearance and antibiotics directed against pathogenic organisms in sputum, usually for 10-14 days [22].

When planning travel, practical advice should be given to prepare the individual for the possibility of experiencing a pulmonary exacerbation. In such cases, increasing the frequency of airway clearance is recommended, and prescribing antibiotics which are active against previous pathogen(s) in sputum to be taken in case of a pulmonary exacerbation is useful, especially for those with a history of previous exacerbations. It is likewise recommended to plan with the person with bronchiectasis to step up treatment in different scenarios (e.g. mild or more severe exacerbation, occurrence of haemoptysis). While self-treatment of pulmonary exacerbations may be safe in many cases, it is always useful to know the health facilities in the destination in case self-management fails. It likewise may not be feasible to rely on oral antibiotics in those with very severe bronchiectasis, those with respiratory failure or people chronically infected with highly resistant organisms, for which intravenous antibiotics are indicated in exacerbations. Likewise, people with bronchiectasis should be educated about occurrence of haemoptysis, in which medical care is usually required.

\section{Discussion}

People with bronchiectasis frequently travel for leisure or business. It is desirable for people with any chronic illness to engage in activities that keep them socially active, and therefore find ways for them to carry on their travelling plans while not compromising regular treatment. The key to keeping healthy while travelling is planning ahead. This involves considering several key factors: those related to the severity of bronchiectasis (presence of chronic infection, respiratory insufficiency, and frequency of exacerbations); those related to the destination (climate, air quality, endemic microorganisms, availability of healthcare, planned activity), and finally, those related to transportation (including mode of travel (air or surface), time in transport and at airports, and conditions, including storage and access to electricity during travel). Knowing these factors is necessary for "tailoring" recommendations to the patient and the journey.

With very little evidence available on the questions raised, it was not possible to make strong recommendations, and all recommendations are based on "expert opinion". This document is designed to 
provide advice to patients and physicians regarding travel and should not be confused with a clinical practice guideline. Although many statements that were considered did not reach a high level of agreement; it should be noted that almost all of these statements may be true for certain people with certain conditions: tailoring these recommendations is necessary when planning travel.

This document is the result of a collaboration between the bronchiectasis PAG volunteers coordinated by the ELF, and bronchiectasis experts affiliated to the EMBARC collaboration. Questions were raised and refined by members of the PAG, who also participated in the writing of this document. Regarding statements that were not included as recommendations: it was commented repeatedly by the respondents that while some of these recommendations may be considered in certain situations, applying them to the entire population of people with bronchiectasis and all travel scenarios may result in unnecessary limitations. It is therefore advised to consider other aspects of travelling not addressed here in advising patients before travel.

\section{Conclusion}

Most people with bronchiectasis can safely travel for leisure or business. Planning ahead is essential to maintaining health while enjoying available activities.

Acknowledgements: The authors would like to thank the following bronchiectasis experts who answered the questionnaire. Lucy Morgan (University of Sidney, Sidney, Australia), Montserrat Vendrell (University of Barcelona, Barcelona, Spain), Apostolos Bossios (Karolinska Institute, Stockholm, Sweden), Gregory Tino (University of Pennsylvania, Philadelphia, PA, USA), Anthony De Soyza (Freeman Hospital, Newcastle upon Tyne, UK), Raja Dhar Respiratory and Sleep Medicine, Fortis Hospital, Kolkata, West Bengal, India, Eva Polverino (Pneumology Dept, Hospital Universitari Vall d'Hebron, Barcelona, Spain), Stefano Aliberti ( University of Milan, Milan, Italy), Menno van der Eerden (Erasmus University Rotterdam, the Netherlands), Adam Hill (University of Edinburgh, Edinburgh, UK), Rosario Menendez (Hospital la Fe, Valencia, Spain), Pierre-Régis Burgel (Université Paris Descartes, Paris, France), Robert Wilson (Imperical College, London, UK), Charles Haworth (Royal Papworth Hospital, Cambridge, UK), Francesco Blasi (University of Milan, Milan, Italy), Conroy Wong (Middlemore Hospital, Auckland, New Zealand), Alan Barker (Oregon Health and Science University, Portland, Oregon), Michal Shteinberg (Technion- Israel Institute of Technology, Haifa, Israel), Timothy Aksamit (Mayo clinic, Rochester, MN, USA), Felix Ringshausen (Hannover Medical School, Hannover, Germany), Antoni Torres (AffiliationsThorax Institute, Institute of Biomedical Research August Pi Sunyer, University of Barcelona, Barcelona, Spain), Katerina Dimakou (5th Dept of Pulmonary Medicine, Sotiria Chest Diseases Hospital, Athens, Greece), Miguel Angel Martinez-Garcia (Valencia University, Valencia, Spain), John Hurst (University College London, London, UK), Michael Loebinger (Imperical College, London, UK), Marc Miravitlles (University Hospital Vall d'Hebron, Barcelona, Spain), James Chalmers (Scottish Centre for Respiratory Research, University of Dundee, Dundee, UK) and Pieter Goeminne (Dept of Respiratory Disease, AZ Nikolaas, Sint Niklaas, Belgium).

Conflict of interest: M. Shteinberg reports travel grants and speaker's fees from GSK, travel grants from Novartis, Actelion and Rafa, grants from Trudell pharma, speaker's fees from Astra Zeneca and Teva, an advisory fee from Horizon pharma, and an advisory fee and speaker's fees from Boehringer Ingelheim, outside the submitted work. M. Shteinberg is a member of the EMBARC management board, leading Work Package 6: Patient engagement activities. B. Crossley has nothing to disclose. T. Lavi has nothing to disclose. S. Nadler has nothing to disclose. J. Boyd is an employee of the ELF. F.C. Ringshausen reports research support, consulting, lecture fees and support for (patient) educational events from Bayer HealthCare and Grifols Germany; research support, consulting, lecture fees, support for (patient) educational events and clinical trial participation from Insmed Germany; lecture and consulting fees from AstraZeneca; lecture fees, support for (patient) educational events and clinical trial participation from Chiesi; lecture fees, research support, support of (patient) educational events and clinical trial participation from Novartis; research support and support for (patient) educational events from InfectoPharm; clinical trial participation for Vertex, Parion, Celtaxsys, Corbus and GSK; research support from Polyphor; lecture fees, support for (patient) educational events and clinical trial participation from Boehringer Ingelheim; consulting and clinical trial participation for Zambon; research support and support for (patient) educational events from Baslilea; and clinical trial participation for Algipharma, all outside the submitted work. T. Aksamit has nothing to disclose. J.D. Chalmers reports that he was a member of a Novartis consortium during the conduct of the study. He reports research grants for COPD studies from Glaxosmithkline, Boehringer Ingelheim, AstraZeneca and Pfizer, grants and personal fees for research into bronchiectasis from Bayer Healthcare and Grifols, consulting fees from Napp and the Aradigm Corporation, and grants and personal fees from Insmed, outside the submitted work. P. Goeminne reports personal fees and nonfinancial support from Chiesi, and personal fees from AstraZeneca, outside the submitted work.

Support statement: EMBARC is a European Respiratory Society Clinical Research Collaboration. This work has received support from the EU/EFPIA Innovative Medicines Initiative Joint Undertaking iABC grant agreement number 115721. Funding information for this article has been deposited with the Crossref Funder Registry.

Members of the ELF Bronchiectasis PAG: Tove Berg, Alan Timothy, Thomas Ruddy, Bridget Harris, Marta Almagro Barbara Crossley, Ernie Lloyd, Annette Posthumus, Nicola Pilkington, Connie Cluderay, Sima Nadler, Pam Carter and Evan Cosgrove.

\section{References}

1 Chalmers JD, Chang AB, Chotirmall SH, et al. Bronchiectasis. Nat Rev Dis Primers 2018; 4: 45.

2 McShane PJ, Naureckas ET, Tino G, et al. Non-cystic fibrosis bronchiectasis. Am J Respir Crit Care Med 2013; 188: 647-656. 
3 Aliberti S, Polverino E, Chalmers JD, et al. The European Multicentre Bronchiectasis Audit and Research Collaboration (EMBARC) ERS clinical research collaboration. Eur Respir J 2018; 52: 1802074.

4 Chalmers JD, Timothy A, Polverino E, et al. Patient participation in ERS guidelines and research projects: the EMBARC experience. Breathe (Sheff) 2017; 13: 194-207.

5 Chalmers JD, Ringshausen FC, Harris B, et al. Cross-infection risk in patients with bronchiectasis: a position statement from the European Bronchiectasis Network (EMBARC), EMBARC/ELF patient advisory group and European Reference Network (ERN-Lung) Bronchiectasis Network. Eur Respir J 2018; 51: 1701937.

6 Hirche TO, Bradley J, d Alquen D, et al. Travelling with cystic fibrosis: recommendations for patients and care team members. J Cyst Fibros 2010; 9: 385-399.

7 British Thoracic Society Fitness to Dive Group, Subgroup of the British Thoracic Society Standards of Care Committee. British Thoracic Society guidelines on respiratory aspects of fitness for diving. Thorax 2003; 58: 3-13.

8 Lim MLW, Brazzale DJ, McDonald CF. 'Is it okay for me to...?' Assessment of recreational activity risk in patients with chronic lung conditions. Aust Fam Physician 2012; 41: 852-854.

9 Ergan B, Akgun M, Pacilli AMG, et al. Should I stay or should I go? COPD and air travel. Eur Respir Rev 2018; 27: 180030 .

10 Ahmedzai S, Balfour-Lynn IM, Bewick T, et al. Managing passengers with stable respiratory disease planning air travel: British Thoracic Society recommendations. Thorax 2011; 66: Suppl. 1, i1-30.

11 Eichhorn L, Leyk D. Diving medicine in clinical practice. Dtsch Arztebl Int 2015; 112: 147-157.

12 Stream JO, Luks AM, Grissom CK. Lung disease at high altitude. Expert Rev Respir Med 2009; 3: 635-650.

13 Seys SF, Daenen M, Dilissen E, et al. Effects of high altitude and cold air exposure on airway inflammation in patients with asthma. Thorax 2013; 68: 906-913.

14 Goeminne PC, Cox B, Finch S, et al. The impact of acute air pollution fluctuations on bronchiectasis pulmonary exacerbation: a case-crossover analysis. Eur Respir J 2018; 52: 1702557.

15 Garcia-Olivé I, Stojanovic Z, Radua J, et al. Effect of air pollution on exacerbations of bronchiectasis in Badalona, Spain, 2008-2016. Respiration 2018; 96: 111-116.

16 Chalmers JD, Aliberti S, Filonenko A, et al. Characterization of the "frequent exacerbator phenotype" in bronchiectasis. Am J Respir Crit Care Med 2018; 197: 1410-1420.

17 Shteinberg M, Stein N, Adir Y, et al. Prevalence, risk factors and prognosis of nontuberculous mycobacterial infection among people with bronchiectasis: a population survey. Eur Respir J 2018; 51: 1702469.

18 Henkle E, Aksamit TR, Barker AF, et al. Pharmacotherapy for non-cystic fibrosis bronchiectasis: results from an NTM Info \& Research patient survey and the Bronchiectasis and NTM Research Registry. Chest 2017; 152: $1120-1127$.

19 Aksamit TR, O'Donnell AE, Barker A, et al. Adult patients with bronchiectasis: a first look at the US bronchiectasis research registry. Chest 2017; 151: 982-992.

20 Faverio P, Stainer A, Bonaiti G, et al. Characterizing non-tuberculous mycobacteria infection in bronchiectasis. Int J Mol Sci 2016; 17: E1913.

21 Máiz L, Girón R, Olveira C, et al. Prevalence and factors associated with nontuberculous mycobacteria in non-cystic fibrosis bronchiectasis: a multicenter observational study. BMC Infect Dis 2016; 16: 437.

22 Polverino E, Goeminne PC, McDonnell MJ, et al. European Respiratory Society guidelines for the management of adult bronchiectasis. Eur Respir J 2017; 50: 1700629.

23 Electronic Medicines Compendium. www.medicines.org.uk/emc/ Date last accessed: March 19, 2019.

24 Vijayan V. Individualizing immunization for international travelers. J Fam Pract 2017; 66: E1-E6.

25 Mirasoglu B, Aktas S. Turkish recreational divers: a comparative study of their demographics, diving habits, health and attitudes towards safety. Diving Hyperb Med 2017; 47: 173-179.

26 Divers Alert Network. Demographics and illness prevalence in recreational scuba divers. www.diversalertnetwork. org/medical/articles/Demographics_And_Illness_Prevalence_in_Recreational_Scuba_Divers Date last accessed: February 16, 2019.

27 Friehs I, Friehs GM, Friehs GB. Air embolism with bilateral pneumothorax after a five-meter dive. Undersea Hyperb Med 1993; 20: 155-157.

28 Buzzacott P, Pollock NW, Rosenberg M. Exercise intensity inferred from air consumption during recreational scuba diving. Diving Hyperb Med 2014; 44: 74-78.

29 Hill AT, Haworth CS, Aliberti S, et al. Pulmonary exacerbation in adults with bronchiectasis: a consensus definition for clinical research. Eur Respir J 2017; 49: 1700051. 